\title{
Ana Koren
}

University of Ljubljana, Slovenia

\section{An Honest Attempt to Grasp and Possibly Tame the Wild Animal of Punning Taxonomy}

\section{Summary}

The paper addresses the issue of the English pun and its successful evasion of taxonomic organization throughout the literature. Many linguists have tried to ground this subject, some going about it with more or less attention to detail, others by dodging the matter altogether. How does one specify and categorize such a phenomenon that spreads its tentacles through so many fields of a language (or even more than one language)? Puns tend to overlap in structure and are therefore almost impossible to divide clearly, by means of providing an untainted example, without interferences of other possible categories. Therefore, some previous approaches to the matter will be presented, followed by an attempt to create a clear categorization of English puns on the basis of various sources and fundamental criteria, recognising a variety of mechanisms that are present in each assigned category. For a better taxonomical comprehension a visual depiction of the tree structure is added. Additionally, unintentional punning and a short circuit in discourse, or the misinterpretation of puns, will be presented and briefly discussed.

Key words: pun, wordplay, taxonomy, punning, language

\section{Taksonomija besednih iger: kako ujeti in ukrotiti to divjo žival}

\section{Povzetek}

Članek obravnava besedne igre v angleščini in njihovo uspešno izogibanje poskusom organizirane razporeditve in razčlenitve. Mnogi jezikoslovci so si prizadevali za jasno klasifikacijo besednih iger, si pomagali z najrazličnejšimi pristopi in pri tem bolj ali manj upoštevali podrobnosti; nekateri pa so se takšni klasifikaciji povsem odrekli zaradi nejasnosti in prekrivanja različnih kategorij. Kako lahko področje, ki razpreda svoje lovke skozi mnoge jezikoslovne principe in vidike jezika (ali celo več jezikov), sploh jasno razdelimo, ko pa se besedne igre tolikokrat prekrivajo v svojih lastnostih in je skoraj nemogoče najti primer, ki ni mešanica mnogih kategorij? Zaradi želje po trdnih temeljih lastne taksonomske ureditve, bom predstavila najrazličnejše pristope, ki so se jih lotevali avtorji pred menoj, nato pa bom na osnovi njihovih dognanj in po jasno zastavljenih osnovnih kriterijih poskusila ustvariti lastno jasno kategorizacijo angleških besednih iger in predstavila dodatne mehanizme, ki pripomorejo $\mathrm{k}$ njihovi uspešni izvedbi. Za preglednejšo klasifikacijo bom v članek vključila vizualno podobo klasifikacije in na kratko omenila tudi problematiko nenamernih besednih iger in napak $\mathrm{v}$ diskurzu, katerih posledica je napačno razumevanje besednih iger.

Ključne besede: besedne igre, kategorizacija, jezik 


\section{An Honest Attempt to Grasp and Possibly Tame the Wild Animal of Punning Taxonomy}

\section{Introduction}

A pun may as well be described as a wild animal which cannot be tamed and kept in a 2-by-4 cage; it lives, evolves, adapts and roams the jungle of languages, ready to be glanced at, petted, or even studied for a short time - but never caught and tamed. In these overly analytical times, it is one of the few creatures that cannot be completely defined and this is what has always inspired the human mind: a mystery that cannot be solved, the untamable.

On several occasions puns were described as "language on vacation" (Redfern 1984, 14) or that they "illuminate language in general" (ibid., 11) and by this, they represent the vast playfulness of a language that successfully evades a complete systematic organisation of its elements. One can perceive and explore these promising possibilities of playful wormholes between the fields of language, which entwine, tangle and interlace in the creation of new puns, while manipulating and moulding the existent vocabulary for the sole purpose of entertainment and amusement.

Even though we encounter a broad spectrum of puns on a daily basis, we rarely let our mind wander beyond their applicative usage into the depths of the linguistic debates, where the true riddles of immense dimensions are uncovered. The boundaries of this linguistic feature are unclear, dazzling and of such great proportions that the observer is usually dumbfounded. It is of great importance to set at least approximate limits (though they may be vague and resemble walking on thin ice), as well as the basic terminology, for the sake of avoiding confusion, and to bind the immense field of punning into a somewhat reasonable enclosure.

The classification of puns is a very tricky business - elusive, unstable and slippery, it acts almost in the same nature as puns themselves. The perfect classification is hard to pinpoint, as the individual instances tend to overlap, simultaneously working on various levels of different linguistic fields.

Many prominent writers and scholars have tried to categorize them properly, but found the task either too confusing, or their typologies have differed greatly amongst themselves. In the words of Evan Esar:

"The variety of puns must be infinite. Years ago I began to write a book on the subject and had little difficulty with its history, literature and other phrases. But when I came to record the different types of puns, I gave up after identifying dozens of different species, for it seemed to be an endless task" (Esar 1954, 70).

In contrast, some scholars have abandoned the thought of punning taxonomy completely. In this spirit, M. Mahood (1968) in her research of Shakespeare's wordplay renounces any attempt of classification by stating that "naming the parts does not show us what makes the gun go off" (ibid., 19; cf. also Culler 1988). Likewise, Walter Redfern elaborates his position vividly: "I am not infatuated with taxonomy, which shares more than its stem with taxidermy" (Redfern 1984, 
5). Brian Vickers, too, shares such an opinion: "One doesn't need to know all or indeed many of the names of the figures to appreciate their existence, for we use them in our everyday speech and writing" (Vickers 1970, 91-2). However true these statements may be, the curious mechanism of the human mind, nevertheless, does not work in such a way and tends to search for order in chaos. Thus, the taxonomy of puns is still very much being investigated by different means, methods, criteria and approaches, the researchers limiting themselves to specific fields of punning or grasping the notion as a whole. ${ }^{1}$ In their paper Visual Puns and Verbal Puns: Descriptive Analogy or False Analogy? (2007), Hempelmann and Samson focus on visual puns (in contrast to verbal puns), placing them into six different categories - from perfect visual puns to no visual pun; Zwicky and Zwicky's study of imperfect puns excludes, among other things, "perfect puns and also those imperfect puns involving stress, word division, languages other than English, speakers indicated as having nonstandard accents ..." (Zwicky and Zwicky 1986, 2). The viewpoints of taxonomical study of punning also differ in approach: Alexander (1997) defines the pun types as graphological, phonological and unintentional, further adding morphological and syntactic levels, and among other things, defining Pig Latin as a type of morphological pun; Chuandao (2005) lists them according to mental realization: the understanding, figurative and logic pun; Raphaelson-West distinguishes between types of jokes and lists puns as "linguistic [jokes]" (Raphaelson-West 1989, 130), the other two being cultural and universal jokes; whereas Eric Pinder, a novel writer, divides them according to their level of humorous effect and subtlety, though, this may be a very subjective criterion:

"...As a connoisseur of puns, I can say with authority that there are three types of pun [...] Category 3: Puns that are so witty, so clever, that you can't help but admire the intellect of the punster. These puns are very rare. Category 2: These puns are so awful, tasteless and groan-worthy that upon hearing them you feel actual physical pain. You may double over in agony. These puns are also rare. Category 1: Puns that are neither particularly clever nor do they inflict much pain, and in fact should probably never have been spoken aloud. Sadly, category 1 puns are the most common." ${ }^{2}$

Other, more common approaches, which most scholars agree upon, tend to analyse the pun species principally by homophony, homonymy and homography, soundplay and wordplay, visual and semantic characteristics.

The majority of basic nomenclature is borrowed from Dirk Delabastita $(1993,1994,1996$, and 1997), Zwicky and Zwicky (1986) and others. In this article, the terms pun and wordplay will be treated as synonyms, whereas word game, non-pun (Delabastita 1997, 2) and spoonerism, ${ }^{3}$

The insight of Heibert (1993) casts a light on this chaos of possible approaches and typology by stating that "the linguistic and textual complexity of wordplay is such that a wide variety of descriptive categories offer themselves as potentially relevant ... Faced with this situation, the taxonomist of the pun has to choose between two evils: either ignore some of these categories to keep the typology down to a manageable size (at the price of reducing its descriptive force), or allow new categories to multiply the number of possible subdivisions (at the risk of at once rendering the classification unwieldy and blurring what the categories have in common)" (Heibert 1993, quoted in Delabastita 1994, 236-7).

Website: Eric Pinder - Nature Writing - Children's Books - Humor: http://www.ericpinder.com, accessed on: on 11 January 2011 The spoonerism is mostly considered a borderline case of paronomasia, as it derives from unintentional slips of the tongue due to neurologistic mechanisms. Even though they are nowadays employed deliberately in order to achieve a humorous effect, they fail to convey a second meaning in majority of cases and are, therefore, only scrambled letters or word games. That is why I have decided to exclude them from the classification. 
which describe the games we play with words and their letters (anagram, palindrome, oxymoron, shiftgram, crossword, etc.) and do not carry double meanings, shall be excluded from the argument altogether. At the same time, the puns included in the following classification have to meet the basic criteria of (1) operating on $2+$ semantic levels (paronomasia), (2) subjective intentionality of deliberation, ((3) possible humorous connotation) and are provided with additional mentioning of mechanisms that take place in each variety.

This is also the basis of my pursuit, where I will endeavour to establish a classification of puns by consulting various sources and authors, trying my best to merge these great minds in the sole purpose of finding the organisation, which somehow combines them all, and at the same time I will try to keep it as transparent as possible. At the beginning of the basic taxonomy, I will also present the mechanisms which the individual type of wordplay exhibits, varying from bare semantic shifts to subject (dis)similarities. Such an appendix to classification seems reasonable in order to interconnect the various approaches, along with keeping the matter simple and clear. However, I have no delusions that my attempt is anywhere near flawless, considering this marginal phenomenon, perhaps only casting the spotlight from a somewhat different, yet still versatile angle.

\section{Methodology}

For the purpose of classification, we first had to build up a database of puns. We tried to find as many different types of puns as possible and a result of this endeavour was a collection of more than 800 puns, paying no attention to their means of execution or appropriateness. This selection was thoroughly studied with regard to various literature on punning and it was handled appropriately for the purpose of the author's BA thesis (cf. Koren 2010) and later for the article at hand. Most examples that constitute the database originate from various humorous pages on the Internet, and some of the puns come from films, sitcoms and daily life.

The distinction between puns and non-puns is established on the basis of three criteria: (1) they operate on different semantic levels, (2) they are deliberate in nature and (3) they carry possible humorous undertone(s). Types of puns were then classified according to (1) their means of execution (basic division vs. visual puns), (2) by their nature of execution (wordplay vs. soundplay) and (3) sorted into groups sharing similar primary mechanisms that take place in a specific class.

\section{Taxonomy}

Upon theoretical and practical work numerous mechanisms were discovered, which function within an individual wordplay. This disclosure was the birth of the idea for a more precise taxonomy. In order to establish a semantic shift, which is necessary for a pun to work its course, nine mechanisms were successfully identified:

1 bare semantic shift: the change is invisible and comprehended only in a form of polysemy of a lexical item;

2 sound shift: slight or obvious change in the phonetic structure; 
3 letter shift: changes in orthography;

4 dispersion or mergence of elements: division or unification of pun elements;

5 misplaced reference: lack of definite reference indication;

6 opaque deliberation stance: speaker's deliberateness is unclear;

7 inclusion of phraseological units: puns involve collocations, idioms, or relatively fixed phraseological units;

8 (cross-)cultural reference: (multi-)cultural background is present;

9 subject (dis)similarity: realization of pun elements shows unity or duality.

Even though the mechanisms appear quite simple and transparent, their manifestation is a far cry from the desired clarity, as they tend to overlap within individual puns almost without exception. However, as overlapping as they might seem, each of them works its way to adding a piece to this language puzzle and revealing a picture of this elusive creature called wordplay. In the course of the main taxonomy, they will be presented in square brackets ([ ] due to better distinction.

The first stage of categorization is the distinction between puns and non-puns upon the basic criteria that they operate on different semantic levels, are deliberate in nature, and carry possible humorous undertone(s). This is followed by the basic division, which corresponds to puns transmitted by either written or spoken language, whereas visual puns are listed separately, as they do transmit the double meaning, however, not via written text or speech, but as a visual image alluding to the existent pun, or creating a double meaning by implying an act that is visually similar to the image. Therefore the visual puns do not fall into the basic division of perfect and imperfect puns/soundplay and wordplay. Unintentional punning and misinterpreted puns are presented as well, though separately, due to the failure of conveying a clear message or a proper recognition of the pun. The reasons for such errors in discourse are discussed briefly. For a better comprehension of this taxonomy I have also included an image of the taxonomic tree structure in the appendix.

A brief outline of the taxonomy is as follows: on the account of the basic criteria (as listed above) I have distinguished punning from a different group of word play (non-puns) and further divided them according to their (1) means of execution (basic division vs. visual puns), (2) nature of execution (wordplay vs. soundplay) and sorted them into groups which share similar primary mechanisms that take place in a specific class of punning. They were respectively divided amongst the basic division (puns in the form of written or spoken language), visual puns (realisation of the image component brought forward by an existent pun or some other visual imagery) and unintentional punning together with misinterpreted puns. The basic division constitutes of two major groups: perfect and imperfect puns, the latter segregated into two extensive classes of soundplay and wordplay, which are composed of six and seven subdivisions respectively. Each of these subdivisions may or may not further branch out into two interconnected sets of a word- or soundplay. 
A name and appropriate mechanism(s) are assigned to each category of classification; it is accompanied by a short discussion and followed by examples from various sources of contemporary culture.

\subsection{Basic Division}

First, the basic division is divided into soundplay (sound alliteration, approximate homonymy) as seen in the example: Be kind to your dentist, he has fillings too and an actual wordplay (perfect puns: alliteration to a certain meaning, polysemy) (cf. Delabastita 1997), the frustrated cannibal threw up his hands. The puns are transmitted via written or spoken language. The puns listed in the soundplay category can also be referred to as imperfect puns, as they require additional changes to their environment rather than just a bare semantic shift, which is present in some instances of wordplay (perfect puns). However, needless to say, the mentioned classification acts like different shades of grey; puns are rarely purely black and white due to frequent overlaps of types.

\subsubsection{Soundplay}

1 A homophonic pun [letter shift] (also referred to as 'polyptoton') operates with word pairs that sound alike, though they are not synonymous. It occurs when the words taken into account for the wordplay have different spellings but the same pronunciation. Words that carry this possibility are scent vs. sent, jeans vs. genes, buy vs. bye, flees vs. fleas, flu vs. flue vs. flew, to name but a few.

Atheism is a non-prophet institution.

1a A homophonic pun with mergence of elements [letter shift, mergence of elements], where instead of using one word, a number of words are combined to convey another semantic level, employing altered spellings.

\section{Bon A-Pet-Treat! (a pet bakery)}

1b A homophonic pun with dispersion of elements [letter shift, dispersion of elements], where one vocabulary item creates a conceptual illusion of two separate words.

Two vegetables meet. One says to the other: "Hey salad, lettuce get married!"

2 A double-sound pun [sound shift] is a play on words, where the two lexical objects in question sound very similar, though they are not homophonic.

A music teacher not at home may leave a note on their door saying, 'Gone Chopin, Bach in a Minuet'.

3 A homographic pun [sound shift] (also referred to as 'antanaclasis') makes use of different words, which are homographic, but acquire different meanings and pronunciation. A few of such pairs are: bass (/beIs/) vs. bass (/bæs/), wind (/wa I nd/) vs. wind (/w Ind/).

Q: What instrument do fish like to play? A: A bass guitar. 
3a A homographic pun with mergence [sound shift, mergence of elements], where two lexical items merge to achieve a different semantic meaning.

You can tune a guitar, but you can't tuna fish. (Unless, of course, you play bass.)

3b A homographic pun with dispersion [sound shift, dispersion of elements], here a lexical item alludes to another by dispersing into two or more elements.

My Boring Career by A. Driller (imaginary book title), Miss Match (a TV series)

4 A compound pun [sound shift, letter shift, mergence/dispersion of elements] is a sentence, which contains a string of two or more words sounding similar to another lexical unit; it is usually constructed on the basis of phonological similarity.

Q: "Eskimo Christians who?" A: "Eskimo Christians Italian no lies."

(pun on the phrase "ask me no questions, I tell you no lies")

4a A knock-knock joke [all mechanisms are possible] is probably the most famous and the most common use of puns in everyday conversation. It functions on the basis of a dialogue, where the principle is always the same:

Speaker 1 begins with an opening line, which is invariably "Knock, knock."

Speaker 2 then asks "Who's there?"

Speaker 1 answers with the beginning of the pun (e.g. "Banana.")

Speaker 2: "Banana who?"

Speaker 1 finishes the joke: "Banana split so ice creamed!"

In this instance a perfect pun is present, showing the mechanisms of bare semantic shift in the case of split (a polysemous lexical item) and a compound pun based on homophony with mergence and partial dispersion of elements in ice creamed (> I screamed).

Sometimes the obligatory 'who' in the interrogative sentence of the second speaker is also used to make a pun.

"Knock-knock!" "Who's there?" "Dishwasher." "Dishwasher Who?" "Dishwasher way I ushed to shpeak before I got my falsh teesh".

The above example demonstrates a compound pun, based on homophony with letter shift and dispersion of lexical items (dishwasher $=$ this was the).

5 A recursive pun [letter shift] is a unit that contains a symbol, letter, abbreviation or some other indicator that relates to a lexical element similar in sound. Such occurrences can be found with the letter 'P' (standing for 'pee' or 'pea'), K-9 (pronounced /'ke冈na冈n/, a police code for trained dogs); letter ' $\mathrm{C}$ ' (standing for 'see' or 'sea'). It is debatable whether recursive puns should be listed under acronymic puns.

When two egoists meet, it's an I for an I. 
6 An extended pun [sound shift, letter shift] (or 'a pun sequence') is a string of puns in a sentence, made in correlation to one subject. The elements are mostly in homophonic relation to existing lexical items which they allude to, or, as in the present case, to the existing European countries.

I like European food so I decided to Russia over there because I was Hungary. After Czeching the menu, I ordered Turkey. When I was Finnished I told the waiter 'Spain good but there is Norway I could eat another bite.

\subsubsection{Wordplay}

1 Puns with a misplaced subject/object reference

1a A double entendre [misplaced reference, opaque deliberation stance] occurs when a spoken or written statement has the potential of having two meanings, with the exception that the author is either unaware of the second meaning, or has coined the phrase just for the purpose to confuse the receiver of the message, insinuating sexual connotation (or insulting remark) lurking behind the mask of pure coincidence. It is most common in everyday communication, as well as situational humour in movies and television series. Because of the dual nature of English words, simple sentences can be quickly manipulated into sexual innuendos. Most common words like 'do' and 'come' have dangerous 'evil twins' of meaning.

A teacher of English verb writes on the blackboard: "John was happy when Mary came." After a couple of chuckles from the classroom, the teacher notes the double meaning, and with a smile, replaces came with a more harmless arrived.

$1 \mathrm{~b}$ Puns with a misplaced subject/object reference relating to idioms and collocations [misplaced reference, (cross-)cultural reference, inclusion of phraseological units] exploit the number of subjects or objects the anaphorical pronouns (he, she, it, they, them etc.) may refer to. Often we encounter a play on words which seems to lack the exact reference, or it is not clear what they refer to; however, this is the intentional and basic characteristic of the pun. At the same time an idiom or a collocation is present, which creates its double meaning.

\section{I wondered why the baseball was getting bigger. Then it hit me.}

The misinterpreted reference can also happen with certain collocations, where the verb applied can be adhered to various situations.

"Every time I get drunk, I see hundreds of green snakes in my dreams," confided Ray to his friends. "Have you seen a doctor?" asked his friend anxiously. "No, only green snakes."

2 Puns based on idioms [misplaced reference, (cross-)cultural reference, inclusion of phraseological units] (alliteration in meaning and formation) are the most common occurrence of pun-related humour. Punsters exploit the idioms and other established phrases with great pleasure, turning the opaque statement into a literal reference to a certain situation, or just to transmit an additional dimension. Veisbergs meditates on this subject:

"Wordplay based on idioms has a number of interesting peculiarities. It tends to consist of larger 
chunks of text than other types of puns which play on a single word and therefore tend to be more compact. Also, the functional or deliberate nature of idiom-based wordplay is less likely to be a matter of interpretative ambiguity or controversy than with other types." (Veisbergs 1997, 157)

The pun is constructed by taking a well-known phrase or an idiom and applying semantic and/ or structural changes to it (cf. Veisbergs 1997, 155). These puns mainly exploit the similarity between an image component (cf. Dobrovol'skij and Piirainen 2005), which the conveyor of the pun makes advantage of, and the rest of the pun. The main element of this mocking statement it's easy to distract people - it's a piece of cake is an idiom a piece of cake, though without doubt carrying a well-known meaning of something being easy, conducted without effort, at the same time presenting an inner image of a slice of pastry. When the idiom is successfully inserted in the context of the pun, the strong image component enables its execution. This is also a good example of a semantic change: the idiom stays structurally unchanged, yet gains an additional, transparent angle. A structural change, on the other hand, can be observed in the film title Over the Hedge, where the established idiom 'over the edge' not only changes semantically, but also in its orthography, acquiring a new dimension in describing the film in two different manners which is exactly what idiom-based puns are all about. Another example is the phrase often cited among punsters: A day without wordplay is a day without punshine. With the structural change of the idiom, we can visually perceive the difference that took place (orthographic change), whereas with the semantic change applied, it is only visible from the context. When an idiom is transformed into a phrase which acts as the wordplay, it may change its form, yet being so anchored in one's vocabulary (cliché) and at the same time sounding similar, it seems to stay unchanged; the actual transformation being merely noticed as a witty extension and another possible (additional) scope of meaning.

Different structural variations of a single pragmatic idiom (a bird in the hand is worth two in the bush):

- a bird in the hand and one in a bush (a jargon expression for an intimacy avoidance disorder);

- a bird in one hand is worth more than a bush (Ice Cube lyrics);

- a bird in the hand is not as good as a girl in the bush (graffiti).

We could argue that what we frequently encounter in American sitcoms is a visual actualization of idioms - where the visual image creates the twist of the double meaning. The process of the materializing proceeds as an idiom or an established phrase is spoken by a character who immediately finds himself/herself in a situation portraying the phrase's literal meaning. Or the other way around - the character in a certain situation phrases his words in such a manner as to provide an idiom.

[A farmer tried to move the bucket with chicken food, when he tripped, fell, and died from the seriousness of the injuries.] As the medical team arrives, a paramedic remarks smartly: "He surely kicked the bucket." 
3 A reinterpretational pun [dispersion of elements, (cross-)cultural reference] ('daffynition') involves a reinterpretation of an existing word by another word or a group of words which sometimes either define a separate part of the word, or merely sound similar.

$$
\text { decadent }=\text { possessing only ten teeth }
$$

4 A transpositional pun [(cross-)cultural reference, inclusion of phraseological (or rather, wellknown) units] corresponds to rearrangement of words in well-known phrases and uses them as outcomes of reinterpretational puns. However, a transpositional pun is, again, a typical border case, as it is also classified as 'modification of idioms' in the field of phraseology. Where, in fact, they do stand is not completely clear and one could argue either way.

$$
\text { hangover }=\text { the wrath of grapes }
$$

5 An acronymic pun

5a Acronyms with lexical item > acronym formation pattern [mergence of elements, (cross-) cultural reference] are names of various institutions, organizations, titles, even fictive combinations of words, where the initial letter of each word constitutes a humorous word or its approximant (which, most commonly, is a taboo expression).

Account Service Specialist = ASS; Business Union for Training Teams = BUTT; Dedicated Infantry Combat Killer = DICK (used in combat training, US Army); $\quad F$ a $r m i n g$ University of Central Kentucky $=$ FUCK

$5 \mathrm{~b}$ Acronyms with acronym $>$ lexical item formation pattern [letter shift, dispersion of elements, (cross-)cultural reference] operate by taking a familiar abbreviation and 'decode' it to show an individual stance or opinion.

$I B M=I$ Blame Microsoft; $B B C=$ Bye Bye Colonies; $A I=$ Artificial Idiot $; A U D I=$ Always Unsatisfied Driving It; PMS = Potential Murder Suspect

6 A zeugma [bare semantic shift, inclusion of phraseological (collocational) units, subject dissimilarity] portrays a 'double-realization' of the same verb (polysemous verb) which can take various objects to form miscellaneous phrases and exploit collocations along the way. Walter Redfern notes:

"Zeugma, like the pun, is economical: it contracts two sentences into one - it links unrelated terms - mental with moral, abstract with physical, high with low - and thus generates surprise." (Redfern 1984, 95)

We were so poor when I was young, we couldn't even afford to pay attention.

7 The Tom Swifty [bare semantic shift, subject similarity] is named after Tom Swift, a character from the American series of adventure novels for boys, where such plays on words are found in abundance. It describes a type of puns where the wit is based on the relationship between the way an adverb (mostly, though it can also be characterised by an adjective, collocation, idiom, 
etc.) portrays the speaker, and at the same time alluding to the statement or the position which the speaker is in.

\section{"It only looks like cocaine," Tom snorted.}

"Oops! There goes my hat!" said Tom off the top of his head.

8 A bilingual pun [(cross-) culture reference, subject dissimilarity] is made by taking similar lexical items or sequences of words from another language and transferring them into the original language of the sentence; in this spirit, it exploits false friends quite effectively. A few words that can be exploited for such wordplay are $d r y$ (En.) vs. drei (Ger. three); nine (En.) vs. nein (Ger. no); gift (En.) vs. Gift (Ger. poison); fart (En.) vs. fart (Sw. speed); magazine (En.) vs. magazin (Slo. warehouse); photograph (En.) vs. fotograf(Slo. photographer).

Young Mozart performs for the Emperor who offers him a plate of food and asks how many he would like. Mozart replies: "Nein, sir." Emperor exclaims: "Very well then, give him nine. Musicians are like actors - they eat like pigs!"

\subsection{Visual Puns}

Visual puns [bare semantic shift, subject similarity, mergence or dispersion of elements] involve an image (sometimes more than one) with two or more associations or meanings i.e. share the same image component (cf. Dobrovol'skij and Piirainen 2005). They should not be mistaken for cartoon puns where also textual elaboration is present. James Brown $(1956,14)$ is quoted by Redfern $(1984,143)$ claiming there "is no such thing as perceptual pun", but is that not also a play on certain aspect of our perspective with the dual identity? Can we claim that a visual pun is not only restricted to play on words but also expand it to say it is a play on images, where one visual notion apprehends two possible meanings? It seems easily acceptable, yet if so, we have to decide where we stand on optical illusions. Where do we draw the line? This is one more example of the blurry thin line between the wordplay and the mere play. I have further divided visual puns into two categories, depending on their core allusion:

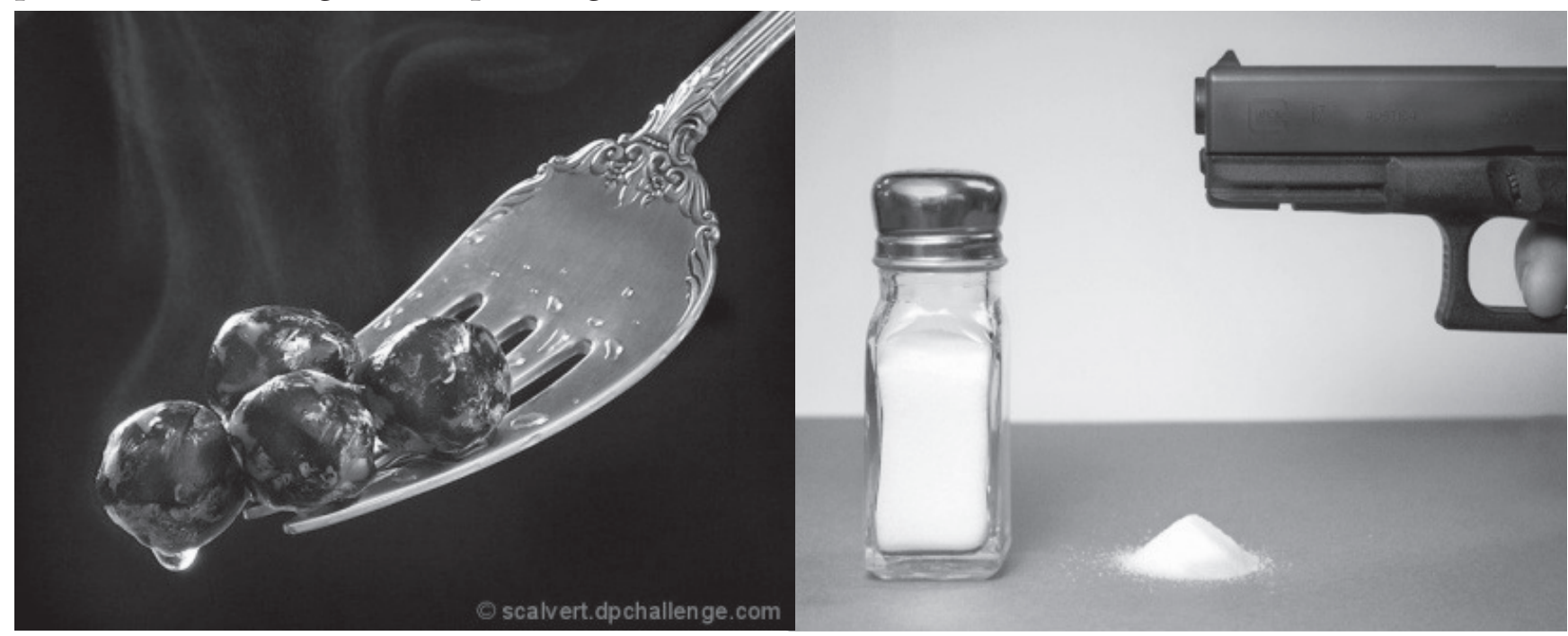

Picture 1. Shannon Calvert, Visualize World Peas (with permission of the author).

Picture 2. Mark Peters, A Salt with a Deadly Weapon (with permission of the author). 
1 Visual puns alluding to existent puns are the purest form of a visual pun. They convey obvious reference to a wordplay which already exists in written form. Visual puns are usually based on a previous knowledge of an established pun, with the difference in transfer, which is also necessary for its decryption. The author uses means of visual images to convey the pun. Contests in visual puns are very popular and they are mostly superbly executed.

2 With visual puns alluding to various actions and states there is a question of whether or not these images which do not employ an existent written pun but are pure associations on their own should be incorporated into this taxonomy at all. We can see thousands of them in everyday life: in visual advertisements, implying sexual acts; in television series and motion pictures; and nevertheless, in our daily conversations, where we gesticulate in a certain way to insinuate another possible association during the conversation. Most famous examples of such visual puns are various associations to sexual acts or reproductive organs in motion pictures. In the Austin Powers trilogy, for example, such allusions to the male sexual organ and sexual intercourse are encountered basically in every scene of the motion picture and are the foundation of its humour.

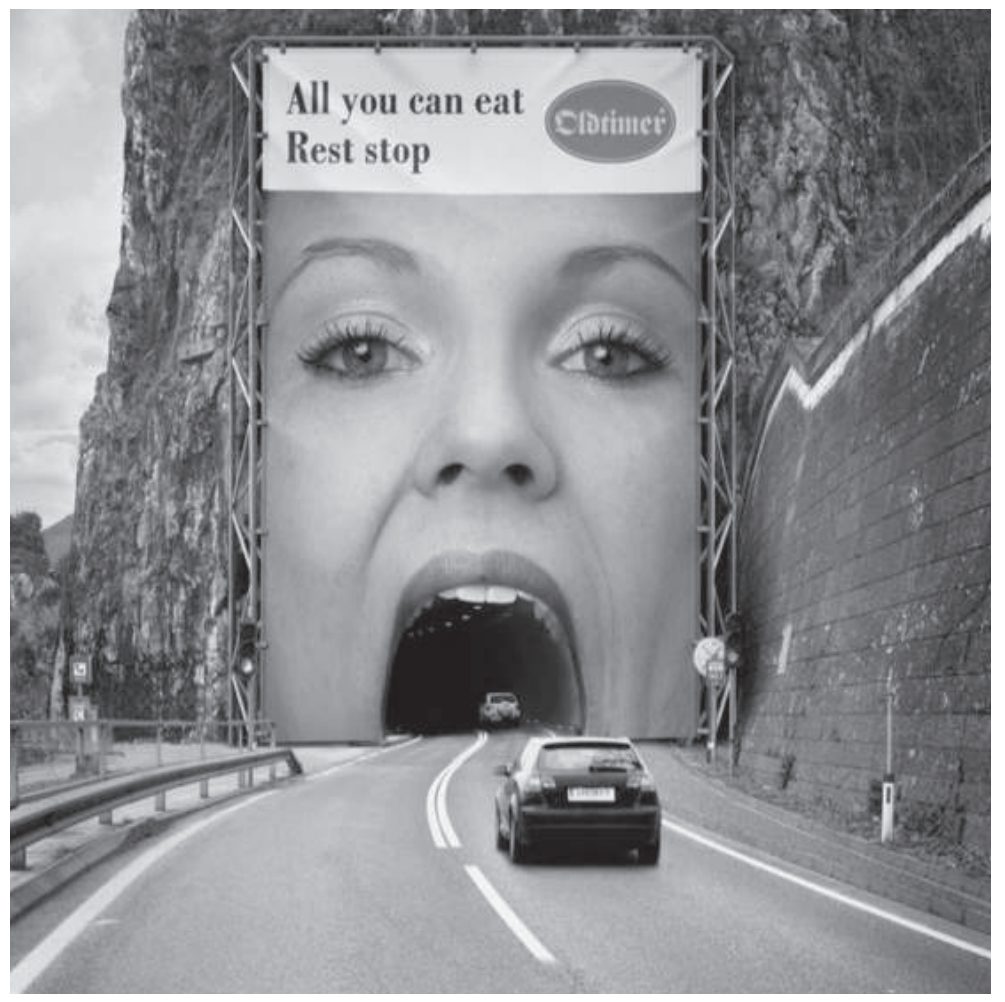

Picture 3. Depiction of a pun alluding to the action of eating in an advertisement for a rest stop (open source).

\subsection{Unintentional Punning and Misinterpreted Puns}

1 Unintentional punning is a problematic subject, as the source (almost without exception) tends to convey a non-dubious message, without humorous undertones. The recipient, however, comprehends the pun instead of the core message. The most serious unintentional punning is present in e.g. road signs, as their main purpose is to convey a clear, non-dubious meaning in a limited number of words. Similarly, such cases can be found on other signs (a drug rehabilitation clinic green area sign Keep off the grass), store windows, restaurant signs (restaurant/gas station: Eat here, get gas), etc. They mostly occur due to the lack of language knowledge or punctuation, are written in a hurry, or - in some cases - are there to get attention (intentionally). However, 
such double meanings are mainly unintentional and sometimes confusing for the observer, but nevertheless very humorous in some instances.

2 Misinterpreted puns, however, are problematic from the recipients' point of view. Punning being a play on words and meanings, it may sometimes happen that they are misinterpreted by the receiver due to an error in discourse.

This happens mainly for four reasons:

1 the receiver of the message has no knowledge of possible polysemy of a specific lexical item used in punning;

2 the receiver has difficulties understanding the vocabulary used;

3 the receiver misplaces the stress of the pun, placing it on the 'wrong' lexical item and searches for double meaning elsewhere than intended;

4 the recipient of the message chooses a different possible meaning of the lexical item.

While the first and second reasons occur due to a possible blind spot in the receiver's knowledge, the third and fourth reasons mostly occur with perfect puns, where there are more than one (possibly) polysemous items present. The consequences of misinterpreted puns may be absence of pun execution as in (1), poor and/or nonsensical execution of the pun as in (2), or a completely new pun.

\section{(1) I have a perfect body but it's in the trunk and beginning to smell.}

The core lexical item on which it is played upon is body, meaning either 'physical manifestation of a human being' or 'a body of a deceased person'. Therefore, the pun would evolve around a dead body in the trunk of a car. However, the pun may wrongfully focus on a polysemous item trunk as "a compartment in the rear of an automobile" or a colloquial expression for a human behind. Needless to say, the execution of the pun would be, putting it mildly, quite odd.

\section{(2) If it's called tourist season, why can't we shoot them?}

The recipient of the message is aware of the core lexical item the semantic change is based on, but fails to recognize which possible meaning fits the puzzle to make it a sensible pun. In this example the receiver links the polysemous word tourist to the lexical item shoot and is convinced that the pun is played upon the word shoot as in 'to shoot with a weapon' and 'to take photographs'. We could argue that the pun is executed, though poorly and lacking a humorous connotation. However, what the recipient failed to recognise is the link between tourist season (appealing to bunting or open season) and shoot as the act of 'killing with a weapon'. In explanation, the correct interpretation of the pun would disclose: if it is called a tourist season, why can't we kill the tourists?

\section{Conclusion}

Even though the taxonomy of puns is in itself a slippery slope, a wild animal to be tamed, taking into account their constant overlap, different viewpoints and more or less attention to detail, it is possible to bind them into reasonably enclosed groups with similar characteristics which may, nonetheless, interact and extend over the drawn line. This is how they most often intrigue the analytical minds of linguists, send them wandering in various directions and remain an 
open debate for numerous possible solutions. Whether the introduced division is the utmost transparent means of the punning taxonomy still remains open to various interpretations and further research, as this article is but a tip of the iceberg. Additional research could, for example, focus on transpositional puns bordering modifications of idioms and, with proper instruments and approaches, position them within one or the other. Similarly, it seems plausible to further investigate recursive puns and whether they could be fitted within acronymic puns. Extensive empirical research of mechanisms functioning in different wordplays is needed in order to observe whether their co-appearance is as coincidental as it may seem at first glance. Puns based on idioms appear to be rich in possibilities as well, especially in terms of cross-cultural and cross-linguistic perspectives, studying their realisation in other languages, mechanisms that contribute to a successful transmission into other language(s) and changes that occur during the transmission.

All in all, this article is an attempt to grasp a single butterfly of punning taxonomy, which by itself seems a complete, whole and fairly complex organism; however, in this vast areas of language punning there are still tigers, birds, whales, flowers and entire ecosystems yet to be perceived and pondered. At this point, it seems reasonable to question, whether this wild animal is indeed to be tamed or left to wander freely through the jungles, nourishing our imagination and appreciation for the language, which fights back when tried to be fitted into a thoroughly analysed file cabinet.

\section{Bibliography}

Alexander, R. 1997. Aspects of Verbal Humour in English. Tübingen: Narr.

Alexieva, B. 1997. There Must be Some System in This Madness. Metaphor, Polysemy and Wordplay in a Cognitive Linguistics Framework. In Delabastita 1997, 137 - 54.

Bergson, H. 2004. Laughter: An Essay on the Meaning of the Comic. Whitefish: Kessinger Publishing.

Brown, J. 1956. Eight Types of Pun. In PMLA, 71. Available at: http://links.jstor.org/sici?sici=00308129\%28195603\%2971\%3A1\%3C14\%3AETOP\%3E2.0.C0\%3B2-I (accessed on 11 January 2012)

Chuandao, Y. 2005. Rhetorical Characteristics of advertising English. In Language in India, ed. M. S. Thirumalai, 5:3, 23-34. Available at: http://www.languageinindia.com/march2005/advertisingenglishhongkong1.html (accessed on 11 January 2012)

Culler, J., ed. 1988. On Puns: the Foundation of Letters. Oxford: Basil Blackwell Inc.

Delabastita, D. 1993. There's a Double Tongue: An Investigation into the Translation of Shakespeare's Wordplay, with Special Reference to Hamlet. Amsterdam and Atlanda: Rodopi.

---. 1994. Focus on the Pun: Wordplay as a Special Problem in Translation Studies. In Target 6: no. 2: 223-43.

---., ed. 1996. Wordplay and Translation. Manchester: St. Jerome Publishing.

---., ed. 1997. Traductio: Essays on Punning and Translation. Manchester: St. Jerome Publishing.

Dobrovol'skij D., and E. Piirainen. 2005. Figurative Language: Cross-cultural and Cross-linguistic Perspectives. Oxford: Elsevier Ltd.

Esar, E. 1954. The Humor of Humor. London: Phoenix House.

Hammond, P., and P. Hughes. 1978. Upon the Pun. London: Butler \& Tanner Ltd.

Hempelmann, C.F. 2003. Paronomasic Puns: Target Recoverability Towards Automatic Generation. West Lafayette: Purdue University. 
Hempelmann, C.F., and A.C. Samson. 2007. Visual Puns and Verbal Puns: Descriptive Analogy or False Analogy? In Popa and Attardo 2007, 180-96.

Hopkins, C.C. 1927. My Life in Advertising. New York: Harper.

Joseph, S.M. 2005. Shakespeare's Use of the Arts of Language. Pennsylvania: Paul Dry Books.

Koren, A. 2010. English Puns in Modern Culture and the Problems of their Translation into Slovene. BA thesis, Filozofska fakulteta, University of Ljubljana.

Mahood, M.M. 1968. Shakespeare's Wordplay. London: Routledge.

Nash, W. 1985. The Language of Humour: Style and Technique in Comic Discourse. London and New York: Longman.

Popa D., and S. Attardo, eds. 2007. New approaches to the Linguistic Humor. Galati: Editura Academica.

Raphaelson-West, D.S. 1989. On the Feasibility and Strategies of Translating Humor. In Meta: Translators' Journal, Special Issue on Humor and Translation, ed. André Clas, 34:1, 128-41. Available at: http://www.erudit.org/revue/meta/1989/ v34/n1/003913ar.pdf (accessed on 11 January 2012)

Redfern, W. 1984. Puns. New York: Basil Blackwell Inc.

---. 1997. Traductio, Puns, Clichés, Plagia. In Delabastita 1997, 261-70.

Veisbergs, A. 1997. The Contextual Use of Idioms, Wordplay, and Translation. In Delabastita 1997, 155-76.

Vickers, B. 1970. Classical Rhetoric in English Poetry: with a new preface and annotated bibliography. London: Macmillian.

Website: Eric Pinder - Nature Writing - Children's Books - Humor: http://www.ericpinder.com, (accessed on 11 January 2012)

Zwicky, A., and E.D. Zwicky. 1986. Imperfect Puns, Markedness, and Phonological Similarity: With Fronds Like These, Who Needs Anemones? In Folia Linguistica 20, no. 3-4: 493-503. Available at: http://www.stanford.edu/ zwicky/imperfectpuns.pdf (accessed on 11 January 2012)

Visual resources, respectively: Visualize World Peas; with permission of the author Shannon Calvert. Author's reference: http:// www.hireimagination.com.

A Salt with a Deadly Weapon; with permission of the author Mark Peters. Author's reference: http://www.markpetersphoto.com.

Webpage: e-Forwards.com - Funny Emails. http://www.e-forwards.com/2010/04/a-few-funny-pictures/all-you-can-eatrest-stop-highway-tunnel-billboard-funny-1/ (accessed on 11 January 2012)

\section{Appendix}

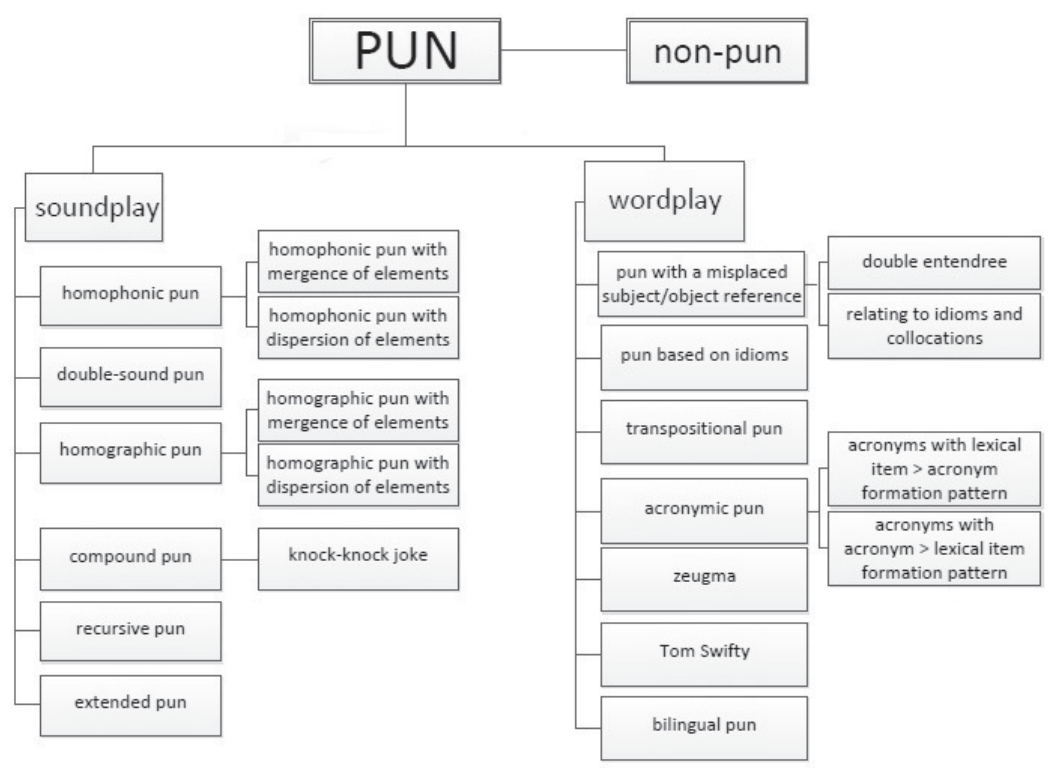

